\title{
Mass balanced models of the food web in three areas along a gradient of eutrophication symptoms in the south arm of the Mondego estuary (Portugal)
}

\author{
Joana Patrício*, João Carlos Marques \\ IMAR - Institute of Marine Research, c/o Department of Zoology, Faculty of Sciences and Technology, \\ University of Coimbra, 3004-517 Coimbra, Portugal
}

\section{A R T I C L E I N F O}

\section{Article history:}

Received 2 November 2005

Received in revised form

20 February 2006

Accepted 3 March 2006

Published on line 18 April 2006

\section{Keywords:}

Ecopath

Ecological model

Estuary

Eutrophication

Trophic structure

\begin{abstract}
A B S T R A C T
Three Ecopath with Ecosim models were constructed to represent the eutrophication gradient along the south arm of the Mondego estuary (Portugal). Sampling was conducted in three areas representative of different environmental situations along the gradient: (a) a non-eutrophic area (Zostera noltii meadows), (b) an intermediate eutrophic area (macrophyte absent, although residual roots can still be found in the sediment, and the occasional formation of abundant macroalgae mats) and (c) a strongly eutrophic area (macrophyte community totally absent for at least a decade and strong, regularly occurring, blooms of Ulva spp.). Field, laboratory and literature information were used to construct the models, as well as empirical ecological knowledge gained from years of work on this system. Approximately 76 trophic groups (e.g. Phytoplankton and Zooplankton species), species and genera were included. These species were grouped into 43, 36 and 34 model groups for Zostera sp. meadows, intermediate eutrophic area and strongly eutrophic area, respectively. The groups were arranged by trophic similarity and habitat preferences; special distinction is given to macrofauna. Biomass, production, consumption, and diet are among the parameters used to describe each group. The sum of consumptions, exports, respiration, production, flow to detritus, total system throughput and annual rate of net primary production was always higher in the Zostera sp. meadows, followed by the strongly eutrophic area and, finally, by the intermediate eutrophic area.
\end{abstract}

(c) 2006 Elsevier B.V. All rights reserved.

\section{Introduction}

Ecology can be defined as the scientific study of the relationships between organisms and their environment; and, in general, can be approached from two directions: (1) via reductionism, wherein each relationship is considered by itself and the results are assembled afterwards; and (2) via holism, whereby the system is considered in its entirety and a search is undertaken to reveal properties at the system level (Jørgensen, 2002).
Previous studies have shown that an ecosystem consists of so many interacting components that it becomes impossible ever to understand how it functions by examining the component relationships in isolation (Likens, 1985; Allen, 1988). Often, when individual components of ecosystems are studied via reductionism, the reconstructed ensemble will behave differently than the sum of the parts.

To obviate such problems, since no system can understand itself, the way it can be understood is to develop simplified

\footnotetext{
* Corresponding author.

E-mail address: jpatricio@ci.uc.pt (J. Patrício).
} 
models which have enough of the characteristics of the original system to resemble reality, but at the same time are simple enough to be understood (Brown, 2004). In fact, one might attempt to describe at least part of the reality of ecosystems structure by developing mass-balance models that represent a static description or a 'snapshot' of the trophic flows in the ecosystem (Christensen, 1994). Such snapshots can be readily compared and therefore, used to explore the evolution of a system through a series of stages or stable states (Christensen and Pauly, 1993). The study of trophic webs has a number of potential advantages, including the likely prediction of negative effects in cascade caused by anthropogenic impacts in ecosystems, and a greater understanding of ecosystem management (Cohen et al., 1993). Assessment of ecosystem health, conservation of living resources and biodiversity could be advanced if the consequences of trophic web modification were predictable (Arias-González et al., 2004). If a trophic network is defined as a model of energy and material flow between organisms via predation processes, then the adjustment (increase or decrease) of elements from the intricate food web and the changes produced in the community structure by this process should produce a disruption in the trophic structure.

From this viewpoint, the main goal of this paper was to construct mass balanced models of the food web in three areas along an eutrophication gradient in the south arm of the Mondego estuary (Portugal), a small and well described temperate intertidal estuary (Marques et al., 1997, 2003; Pardal et al., 2000, 2004; Cardoso et al., 2004; Ferreira et al., 2004; Neto, 2004), using the "Ecopath with Ecosim" software package. This work was a first study of the Mondego estuary using a mass-balance model of trophic interactions.

\section{Material and methods}

\subsection{Study area}

The Mondego estuary, located on the western coast of Portugal, consists of two arms, northern and southern (Fig. 1), with very different hydrological characteristics. The northern arm is deeper, while the southern arm is silted up, especially in upstream areas, which causes most of the freshwater discharge to flow through the northern arm. This siltation diverts most of the freshwater discharge into the northern arm. Consequently, the water circulation in the southern arm is dependent mainly on tidal flushing and on a relatively small input of freshwater from the Pranto River, the flow of which is controlled artificially by a sluice.

Macroalgal blooms of Ulva spp. have regularly been observed in the Mondego over the last 20 years (Flindt et al., 1997; Marques et al., 1997, 2003; Lillebø et al., 1999; Pardal et al., 2000, 2004; Martins et al., 2001; Dolbeth et al., 2003; Cardoso et al., 2004). Nevertheless, such macroalgal blooms may not occur in exceptionally rainy years. This is most probably due to the resulting long periods during which salinity remains below the tolerance limit of macroalgae, coupled with a limitation of phosphorous induced by a heavy nitrogen discharge from the Pranto River (Martins et al., 2001).

Sampling was conducted in three areas in the southern arm of the Mondego estuary that represent different environmental situations along a spatial gradient of eutrophication (Marques et al., 1997, 2003; Lillebø et al., 1999; Pardal et al., 2000, 2004; Dolbeth et al., 2003; Cardoso et al., 2004; Neto, 2004) (Fig. 1): (a) a non-eutrophic area (Zostera noltii Hornem

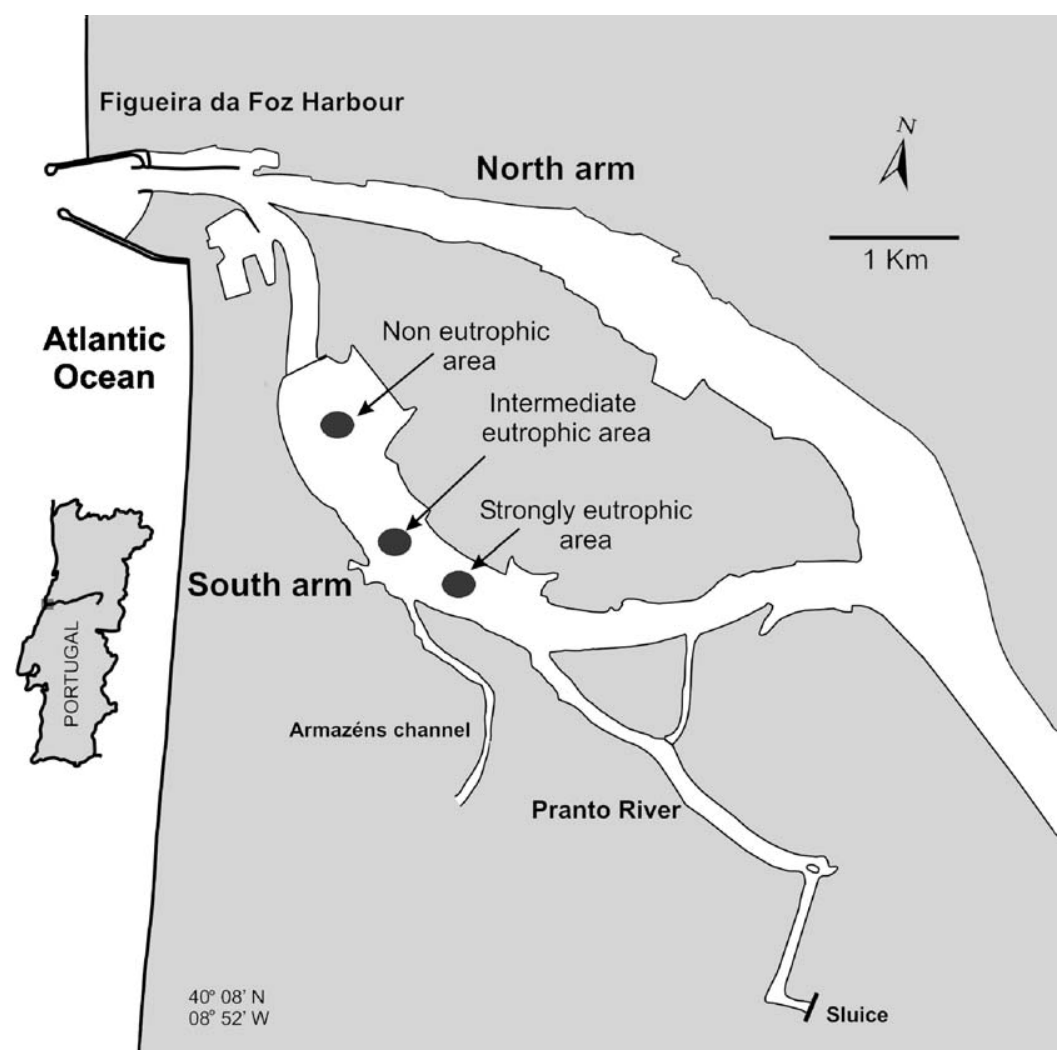

Fig. 1 - Mondego estuary: location of the sampling stations along a spatial gradient of eutrophication. 
beds), (b) an intermediate eutrophic area ( $\mathrm{Z}$. noltii absent, although residual roots can still be found in the sediment, and the occasional formation of abundant macroalgae mats) and (c) a strongly eutrophic area (macrophyte community totally absent for at least a decade and strong, regularly occurring, blooms of Ulva spp.).

\subsection{Methods}

Food webs of the ecosystem in the three areas were constructed using the "Ecopath with Ecosim" software package, which assists the user in casting a balanced carbon budget for each trophic group. The core routine of Ecopath/Ecosim centres on the Ecopath program of Polovina (1984), which was extended to apply to non-steady-state systems (Christensen et al., 2004). It no longer assumes a steady state but instead calculates parameters on the assumption of mass balance over an arbitrary period-usually 1 year. Scores of applications of Ecopath with Ecosim can be found at: http://www.ecopath.org/, along with the freely distributed software and documentation. Although the formulations and basic concepts are accessible in these venues, the general approach is summarised here. When applied, Ecopath derives model parameters on the basis of two master equations. The first equation, describes how the production term for each group can be split in components (Eq. (1)). More specifically, it says that the net production of a functional group equals the sum of (1) the total mass (or energy) removed by predators and fisheries, (2) the net biomass accumulation of the group, (3) the net migration of the group's biomass, and (4) the mass flowing to detritus:

$B_{i} \times(P / B)_{i} \times E E_{i}-\sum_{j=1}^{n} B_{j} \times(Q / B)_{j} \times D C_{j i}-Y_{i}-B A_{i}-E_{i}=0$

where $B_{i}$ and $B_{j}$ are biomasses of prey (i) and predators (j), respectively; $P / B_{i}$ the production/biomass ratio, equivalent to total mortality (Z) in most circumstances (Allen, 1971); $\mathrm{EE}_{i}$ the ecotrophic efficiency; the fraction of the total production of a group utilised in the system; $Y_{i}$ the fisheries catch per unit area and time (i.e., $Y=F \times B$ ); $Q / B_{j}$ the food consumption per unit biomass of $j$; $D C_{j i}$ the fraction of prey $i$ in the average diet of predator $j ; \mathrm{BA}_{i}$ the biomass accumulation rate for $i$; and $E_{i}$ is the net migration of $i$ (emigration less immigration).

In this type of models, the energy input and output of all living groups must be balanced. The basic Ecopath Eq. (1) includes only the production. When balancing a compartment in an ecosystem other flows must be considered. Energy balance is ensured within each group using Eq. (2) (Christensen et al., 2004):

consumption $=$ production + respiration + unassimilated food.

The implied thermodynamic constraints of this equation underscore the power of Ecopath models as a focal point for refinement of ecosystem information. The need to reconcile energy production and demand among components of the food web narrows the possible ranges of parameter estimates for particular groups. Inclusion of a biomass accumulation factor and migration factor in the general Ecopath equation distinguishes Ecopath modelling as an 'energy continuity' approach rather than a strictly 'steady-state' approach. Conservation of energy (continuity) is assumed for every identified component of the ecosystem, and the whole system. This basic constraint enables representation of changes in populations (i.e., functional groups) when expressed in dynamic form.

\subsubsection{Sampling program and laboratory treatment} Chlorophyll $a$, detritus, macroalgae, macrophytes and macrofauna were sampled fortnightly (February 1993-January 1994), during low tide, at each of the three areas. All biological materials were identified and separated into the lowest possible taxa (for more details concerning the technical procedures see Pardal et al., 2000, 2004). Between March 1996 and January 1997 , monthly samples of epiphytes attached to Z. noltii were separated from their substrate, dried and weighed. Zooplankton was collected monthly from sub-surface waters at each sampling site from April 1995 to April 1996, using 200 and $335 \mu \mathrm{m}$ mesh nets (Azeiteiro et al., 1999). Data on fish were taken monthly from January 1991 to December 1992. The captured fish were identified and weighed (wet weight), and the dominant species in the stomach contents were analysed (Jorge et al., 2002). Finally, wading birds were counted from January 1996 to January 1998 at fortnight-tide and monthly low water to provide an accurate census across the three areas (Lopes et al., 2002). Seagulls were counted monthly, from November 1993 to July 1994.

\subsubsection{Compartments}

Species of similar size, diets or with identical ecological niche were grouped. Different numbers of ecosystem compartments were identified in each situation (Table 1): 43 in the Zostera sp. meadows, 36 in the intermediate eutrophic area and 34 in the strongly eutrophic area. Species that were not naturally present in one of the three areas or whose roles in the trophic network were unimportant were not taken into account.

\subsubsection{Biomass (for data sources see Appendix A)}

Chlorophyll $a$ was estimated according to standard procedures (Strickland and Parsons, 1968) and values were transformed into Phytoplankton biomass using a conversion factor taken from Anderson and Williams (1998) and assuming an average depth of $0.5 \mathrm{~m}$ over the sampling area. Epiphytes consisted only of the material attached to the aerial part of $Z$. noltii. Plants and macrofauna were dried at $70^{\circ} \mathrm{C}$ for $72 \mathrm{~h}$ and weighed. The ash free dry weight (AFDW) of biomass was assessed after combusting samples for $8 \mathrm{~h}$ at $450^{\circ} \mathrm{C}$ (Pardal et al., 2000, 2004). The abundance of each Zooplankton taxon was estimated by multiplying the observed number of that taxon by the average AFDW of an individual belonging to it. The weights of all taxa were summed to arrive at the annual average standing stock.

Sixty-two species of fish were observed and grouped according to their ecological and trophic characteristics. The biomass corresponding to each group was determined by multiplying its wet weight by a conversion factor taken from Jørgensen et al. (1991).

The observed density of each bird species was multiplied by the average AFDW of an individual belonging to that taxon (see Appendix A). Although combining bacteria with detritus 
Table 1 - Input data and calculated estimates (in parenthesis) for the three areas (Z, Zostera sp. meadows; I, intermediate eutrophic area; $\mathrm{S}$, strongly eutrophic area) along the eutrophication gradient

\begin{tabular}{|c|c|c|c|c|c|c|c|c|c|c|c|c|}
\hline \multirow[t]{2}{*}{ Groups } & \multicolumn{3}{|c|}{ Biomass } & \multicolumn{3}{|c|}{$P / B^{a}$} & \multicolumn{3}{|c|}{$\mathrm{Q} / \mathrm{B}^{\mathrm{a}}$} & \multicolumn{3}{|c|}{$\mathrm{EE}^{\mathrm{a}}$} \\
\hline & $\mathrm{Z}$ & I & $\mathrm{S}$ & $\mathrm{Z}$ & I & $\mathrm{S}$ & $\mathrm{Z}$ & I & $\mathrm{S}$ & $\mathrm{Z}$ & $\mathrm{I}$ & $\mathrm{S}$ \\
\hline Phytoplankton (A) & 0.336 & 0.324 & 0.17 & 185 & 185 & 185 & - & - & - & 0.772 & $(0.572)$ & $(0.96)$ \\
\hline Enteromorpha sp. (A) & 1.800 & 26.975 & 96.784 & 3.4 & 3.4 & 3.4 & - & - & - & 0.996 & $(0.691)$ & $(0.288)$ \\
\hline Ulva sp. (A) & 0.373 & 2.504 & 7.658 & 3 & 3 & 3 & - & - & - & 0.957 & $(0.883)$ & $(0.984)$ \\
\hline Gracilaria sp. (A) & 16.081 & 2.054 & 2.322 & 3 & 3 & 3 & - & - & - & $(0.033)$ & $(0.084)$ & $(0.044)$ \\
\hline Fucus sp. (A) & & 0.084 & 0.203 & & 3 & 3 & & - & - & & $(0.81)$ & (0.533) \\
\hline Zostera noltii (M) & 204.84 & & & 2.5 & & & - & & & 0.001 & & \\
\hline Epiphytes & 7.695 & & & 180 & & & - & & & 0.149 & & \\
\hline Zooplankton & $(0.348)$ & $(0.278)$ & $(0.234)$ & 22 & 18 & 20 & (73.33) & (90) & $(100)$ & 0.98 & 0.95 & 0.95 \\
\hline Hydrobia ulvae (G) & 54.750 & 4.666 & 9.745 & 1.3 & 4.5 & 4.5 & $(6.5)$ & (22.5) & (22.5) & $(0.209)$ & $(0.224)$ & $(0.092)$ \\
\hline Gibulla umbilicallis (G) & 0.072 & & & 1.76 & & & $(8.8)$ & & & $(0.73)$ & & \\
\hline Littorina spp. (G) & 2.489 & 0.525 & & 3 & 3 & & $(15)$ & (15) & & $(0.082)$ & $(0.468)$ & \\
\hline Melita palmata (Am) & $(0.109)$ & $(0.181)$ & 0.099 & 7.2 & 8.38 & 8.5 & $(36)$ & $(41.88)$ & $(42.5)$ & 0.95 & 0.95 & $(0.973)$ \\
\hline Ampithoe valida (Am) & $(0.236)$ & $(0.179)$ & 0.145 & 5.8 & 4.8 & 4.9 & (29) & $(24)$ & $(24.5)$ & 0.95 & 0.95 & $(0.87)$ \\
\hline Echinogammarus marinus (My) & & & 0.002 & & & 6.3 & & & (31.5) & & & $(0.844)$ \\
\hline Corophium multisetosum (Am) & & 0.002 & & & 10 & & & (50) & & & $(0.635)$ & \\
\hline Scrobicularia plana (B) & 3.260 & 7.762 & 11.347 & 1.8 & 1.8 & 1.8 & (9) & (9) & (9) & $(0.834)$ & $(0.619)$ & (0.319) \\
\hline Cerastoderma edule (B) & 5.221 & 0.088 & 0.216 & 4.8 & 4.8 & 4.8 & (24) & (24) & (24) & $(0.305)$ & $(0.859)$ & $(0.956)$ \\
\hline Modiolus barbatus (B) & 0.022 & & & 2 & & & (10) & & & $(0.446)$ & & \\
\hline Cyathura carinata (I) & 0.056 & 0.343 & 7. 268 & 2.03 & 3.17 & 3.17 & (10.15) & $(15.85)$ & (15.85) & $(0.982)$ & $(0.331)$ & $(0.012)$ \\
\hline Idotea chelipes (I) & 0.040 & 0.027 & 0.02 & 3.8 & 3.8 & 3.8 & (19) & (19) & (19) & $(0.953)$ & $(0.494)$ & $(0.41)$ \\
\hline Sphaeroma hookeri (I) & 0.002 & & & 3.8 & & & (19) & & & $(0.96)$ & & \\
\hline Carcinus maenas (D) & 1.09 & 0.58 & 0.419 & 6.4 & 6.4 & 6.4 & (32) & (32) & (32) & $(0.384)$ & $(0.431)$ & $(0.511)$ \\
\hline Crangon crangon (D) & $(0.132)$ & $(0.317)$ & 0.280 & 6 & 6 & 6 & $(30)$ & (30) & (30) & 0.95 & 0.95 & $(0.964)$ \\
\hline Alkmaria romijni (P) & 0.008 & 0.022 & 0.114 & 2.3 & 2.3 & 2.3 & $(11.5)$ & $(11.5)$ & (11.5) & $(0.443)$ & $(0.69)$ & $(0.804)$ \\
\hline Capitella capitata (P) & 0.006 & 0.062 & 0.038 & 2.4 & 1.6 & 1.6 & $(12)$ & (8) & (8) & $(0.818)$ & $(0.913)$ & $(0.943)$ \\
\hline Heteromastus filiformis (P) & 0.610 & 2.2 & 0.192 & 2.4 & 2.2 & 2.2 & (12) & (11) & (11) & $(0.93)$ & $(0.974)$ & $(0.778)$ \\
\hline Hediste diversicolor $(\mathrm{P})$ & $(0.866)$ & $(0.505)$ & 0.428 & 5.6 & 5.4 & 5.2 & $(28)$ & (27) & (26) & 0.95 & 0.98 & $(0.981)$ \\
\hline Diopatra neapolitana $(\mathrm{P})$ & 0.019 & & & 6.52 & & & $(32.6)$ & & & $(0.914)$ & & \\
\hline Nephtys hombergii (P) & 0.052 & 0.055 & & 4.6 & 4.6 & & (23) & (23) & & $(0.931)$ & $(0.346)$ & \\
\hline Lumbrineris impatiens $(\mathrm{P})$ & 0.130 & & & 2.4 & & & $(12)$ & & & $(0.734)$ & & \\
\hline Other macrofauna detritivores $(\mathrm{P})$ & 0.600 & 0.893 & 0.160 & 2.9 & 2.4 & 2.4 & $(14.5)$ & $(12)$ & $(129)$ & $(0.983)$ & $(0.784)$ & (0.919) \\
\hline Other macrofauna predators $(\mathrm{P})$ & 0.355 & 0.053 & 0.010 & 3.43 & 3.43 & 3.43 & $(17.15)$ & (17.15) & $(17.16)$ & $(0.835)$ & $(0.822)$ & $(0.90)$ \\
\hline Oligochaets & 0.127 & 0.031 & 0.005 & 2.6 & 2.6 & 2.6 & (13) & (13) & (13) & $(0.948)$ & $(0.884)$ & $(0.483)$ \\
\hline Microalgae and detritus feeders (F) & 1.685 & 0.894 & 1.1 & 0.51 & 0.49 & 0.51 & 10.5 & 10.5 & 10.5 & $(0.719)$ & $(0.687)$ & $(0.821)$ \\
\hline Zooplankton consumers (F) & $(0.335)$ & $(0.102)$ & $(0.063)$ & 1.3 & 1 & 1 & 7.44 & 7.44 & 7.44 & 0.95 & 0.95 & 0.95 \\
\hline Endofauna consumers (F) & 0.060 & 0.06 & 0.06 & 0.8 & 0.77 & 0.77 & 3.1 & 3.1 & 3.1 & $(0.79)$ & $(0.617)$ & $(0.870)$ \\
\hline Macrofauna predators (F) & 0.314 & 0.14 & 0.136 & 0.54 & 0.9 & 0.9 & 9.66 & 9.66 & 9.66 & $(0.347)$ & $(0.771)$ & $(0.789)$ \\
\hline Trigla lucerna (F) & 0.020 & & & 1.4 & & & (7) & & & 0.95 & & \\
\hline Pomatoschistus (F) & $(0.031)$ & & & 1.7 & & & $(8.5)$ & & & 0.95 & & \\
\hline Larus ridibundus (Gu) & 0.006 & 0.006 & 0.006 & 0.02 & 0.15 & 0.15 & 0.24 & 0.24 & 0.24 & $(0.000)$ & $(0.000)$ & $(0.000)$ \\
\hline Larus fuscus (Gu) & 0.005 & 0.006 & 0.006 & 0.02 & 0.15 & 0.15 & 0.24 & 0.24 & 0.24 & $(0.000)$ & $(0.000)$ & $(0.000)$ \\
\hline Charadrius alexandrinus (W) & 0.001 & 0.001 & 0.001 & 0.02 & 0.15 & 0.15 & 0.24 & 0.24 & 0.24 & $(0.000)$ & $(0.000)$ & $(0.000)$ \\
\hline Charadrius hiaticula (W) & 0.001 & 0.001 & 0.001 & 0.02 & 0.15 & 0.15 & 0.24 & 0.24 & 0.24 & $(0.000)$ & $(0.000)$ & $(0.000)$ \\
\hline Pluvialis squatarola (W) & 0.001 & 0.002 & 0.002 & 0.02 & 0.15 & 0.15 & 0.24 & 0.24 & 0.24 & $(0.000)$ & $(0.000)$ & $(0.000)$ \\
\hline Calidris alpina (W) & 0.001 & 0.005 & 0.005 & 0.02 & 0.15 & 0.15 & 0.24 & 0.24 & 0.24 & $(0.000)$ & $(0.000)$ & $(0.000)$ \\
\hline Detritus & 527.31 & 518.76 & 309.8 & - & - & - & - & - & - & $(0.184)$ & $(0.826)$ & $(0.675)$ \\
\hline
\end{tabular}

A, macroalgae; M, macrophyte; G, Gastropoda; Am, Amphipoda; B, Bivalvia; I, Isopoda; D, Decapoda; P, Polychaeta; F, fish; Gu, gull; W, wader.

${ }^{\text {a }} \mathrm{P}$, production; $\mathrm{B}$, biomass; $\mathrm{Q}$, consumption; EE, ecotrophic efficiency.

can be problematic using the Ecopath software package, bacterial biomass was assigned to the detritus compartment, as recommended by Christensen and Pauly (1992). Finally, the amount of organic matter in the sediment was assessed to be the weight lost after combustion of dry samples for $8 \mathrm{~h}$ at $450^{\circ} \mathrm{C}$.

\subsubsection{Production, consumption and diet composition}

Production refers to the increase of living tissue within a compartment over a given period. Whenever possible, production/biomass ratios $(P / B)$, previously calculated for local populations (e.g. Marques et al., 1994; Lillebø et al., 1999; Pardal et al., 2000; Ferreira et al., 2004), were used. When this was not feasible, values taken from the literature (Appendix A) were utilised. Special care was exercised to identify values coming from similar Portuguese estuarine systems.

Consumption is the intake of food by a group over a given interval of time. It was entered into Ecopath as the ratio of consumption to biomass $(\mathrm{Q} / \mathrm{B})$. $\mathrm{Q} / \mathrm{B}$ values for birds and fish 
were taken from the literature (Appendix A). For the other heterotrophic compartments, the $P / Q$ ratios were entered into the program to estimate indirectly the $Q / B$ ratio (Hostens and Hamerlynck, 1994).

In a trophic model, such as those constructed using the Ecopath, it is predation that links the different groups into a system. Consumption for one group becomes mortality for another, making information on predation paramount to understand the dynamics of ecosystems. Unfortunately, quantitative information on diet composition is sparse. Diet information for almost all the compartments here identified had to be obtained from the literature (e.g. Hughes, 1969; Costa, 1982; Pihl, 1985; Zajac, 1986; Sprung, 1994; Ansell et al., 1999; Azeiteiro et al., 1999; Cunha et al., 2000; Pardal et al., 2000, see Appendix A). Initially, all prey items of each compartment of macrofauna and fishes were listed, along with their corresponding percentages of occurrence. Each observed dietary item was then assigned to an ecologically similar species or group of species as identified in (2) above. Finally, the percentage of occurrence in the diet was assumed to be proportional to the fraction that its biomass comprised of the total biomass of the group. The diets of wading birds and gulls were obtained directly from an analysis of their droppings (Moreira, 1995; Cabral et al., 1999).

\subsubsection{Captures}

A complete network requires estimates of the rates of export from the system, including the harvests of economically important species. In the present work, the harvests of the bivalve Scrobicularia plana and the polychaete Hediste diversicolor (the only two species of economic importance on the Mondego estuary) were considered small enough to be negligible.

\subsubsection{Balancing the models}

For each of the three models the software has calculated the missing parameters. At first none of the models were balanced (e.g. negative flows to detritus, ecotrophic efficiencies higher than 1-which indicated that the demand on them was too high to be sustainable - and some $P / Q=G E$ values physiologically unrealistic). Given the distinct data and parameters source, this situation was predictable in advance. An exhaustive set of guidelines for how a model should be balanced cannot be given. However, according to the methodology proposed by Christensen et al. (2004), the following procedures were followed.

The quality of the data used for each group in the models was variable. For some, there were empirical estimates available from samples taken from within the models areas and time frame (e.g. all macrofauna, macrophytes, macroalgae). For others it was necessary to use empirical data from other areas and/or time frames (e.g. fishes, gulls) or less specific information (e.g. Zooplankton, Phytoplankton). The most reliable data were macrofauna biomass and production, contrary to the majority of studies (e.g. Bundy et al., 2000; Heymans and Baird, 2000). Data proceeding from the south arm of the Mondego estuary (primary producers, macrofauna, waders and detritus biomass, as well as $P / B$ ratios calculated from previous studies at the some location) were left unchanged. Therefore, greater confidence was placed on them. One exception was the decapods (Crangon crangon and Carcinus maenas) biomass. This parameter had to be estimated due to the fact that the original values were underestimated owing to the sampling strategy used. This was also true for the majority of the fish groups' biomass. Regarding the Zooplankton, due to its complex tidal and seasonal dynamics, it was difficult to estimate a realistic annual average biomass. Thus, the software has calculated the missing parameter for the three models. For subsequent balancing it was necessary to re-evaluate some compartments' diet compositions (e.g. C. maenas, C. crangon, $H$. diversicolor, Lumbrineris impatiens and some fish groups) since feeding habits of some organisms are highly labile and mainly depend on food sources that are available in the ecosystem. This parameter was poorly known, yet it had a large influence on the model estimates.

\section{Results and discussion}

Diagrams showing the trophic flows were constructed, while a summary of all the final input data and the calculated parameters is found in Table 1.

\subsection{Summary statistics}

Table 2 summarises the ecological statistics and indices for the three estuarine networks.

Table 2 - Summary of ecological statistics/indices for the three estuarine networks

\begin{tabular}{|c|c|c|c|}
\hline \multirow[t]{2}{*}{ Statistic/indices } & \multicolumn{3}{|c|}{ Area } \\
\hline & Zostera sp. meadows & Intermediate eutrophic & Strongly eutrophic \\
\hline Sum of all consumption (g AFDW m ${ }^{-2} \mathrm{yr}^{-1}$ ) & 694.91 & 292.14 & 521.33 \\
\hline Sum of all exports ( $\mathrm{gAFDW} \mathrm{m}^{-2} \mathrm{yr}^{-1}$ ) & 1707.51 & 34.01 & 169.61 \\
\hline Sum of all respiration $\left(\mathrm{g}\right.$ AFDW $\mathrm{m}^{-2} \mathrm{yr}^{-1}$ ) & 2322.55 & 297.32 & 612.67 \\
\hline Sum of all flows into detritus ( $\mathrm{g}$ AFDW $\mathrm{m}^{-2} \mathrm{yr}^{-1}$ ) & 2092.06 & 195.09 & 522.40 \\
\hline Sum of all production ( $\mathrm{g}$ AFDW $\mathrm{m}^{-2} \mathrm{yr}^{-1}$ ) & 2151 & 223 & 494 \\
\hline Total system throughput (g AFDW m ${ }^{-2} \mathrm{yr}^{-1}$ ) & 6817 & 819 & 1826 \\
\hline Net primary production (g AFDW m ${ }^{-2} \mathrm{yr}^{-1}$ ) & 2014.83 & 165.58 & 391.065 \\
\hline Total primary production/total respiration & 0.868 & 0.557 & 0.638 \\
\hline Total biomass/total system throughput & 0.045 & 0.061 & 0.076 \\
\hline Total biomass (no detritus) (g AFDW m ${ }^{-2}$ ) & 304.18 & 49.91 & 139.24 \\
\hline Omnivory index & 0.105 & 0.110 & 0.202 \\
\hline
\end{tabular}


The sum of consumptions, exports, respiration, production, and flow to detritus was always higher in the Zostera sp. meadows, followed by the strongly eutrophic area and, finally, by the intermediate eutrophic area. This is also the conclusion reached examining the trends for the total throughput (the sum of all flows: consumption, exports, respiratory flows, and flows to detritus) at each trophic level: $6817 \mathrm{~g} \mathrm{AFDW} \mathrm{m}^{-2} \mathrm{yr}^{-1}$ in $\mathrm{Z}$. noltii meadows, $1826 \mathrm{gAFDW} \mathrm{m}^{-2} \mathrm{yr}^{-1}$ in the strongly eutrophic area and $819 \mathrm{gAFDW} \mathrm{m}^{-2} \mathrm{yr}^{-1}$ in the intermediate eutrophic area (Table 2). All these results are, partially, explainable because the non-eutrophic area model has more groups than the other models. This higher number of compartments has an impact on the calculations and increases the TST and subsequently all the flows such as consumption, production, etc. Both eutrophic areas presented a similar partitioning of the total throughput, between 29 and $36 \%$ of the total was due to consumption, approximately 4-9\% was exported, about 24-28\% flowed into detritus, and around 34-36\% was respired (Fig. 2).

The major difference verified in the non-eutrophic area concerned a proportionally higher value $(25 \%)$ due to exports. What is the explanation for these differences in the breakdown of throughput, with so much more exports and flow to detritus in the Zostera sp. meadows? It is well known that macrophytes support two types of food webs; first, an herbivorous web in which herbivorous feed directly on the standing plant or on the attached epiphytes, and second, a detritivorous web, were some species feed on plant detritus. According to Enriques et al. (1993), macrophytes are major producers of organic matter but little of this production enters the grazing food chain because there is a time lag between the production and its utilisation.

Therefore, only few animals feed directly on these plants (their production is usually used after decomposition) and a big proportion of the production decays to detritus or is washed way from the production area, being used in other systems. This fact is consistent with the results of the current study.

The annual rate of net primary production presented a similar behaviour, clearly related with the primary producers dynamic in each of the studied areas. A long-term study

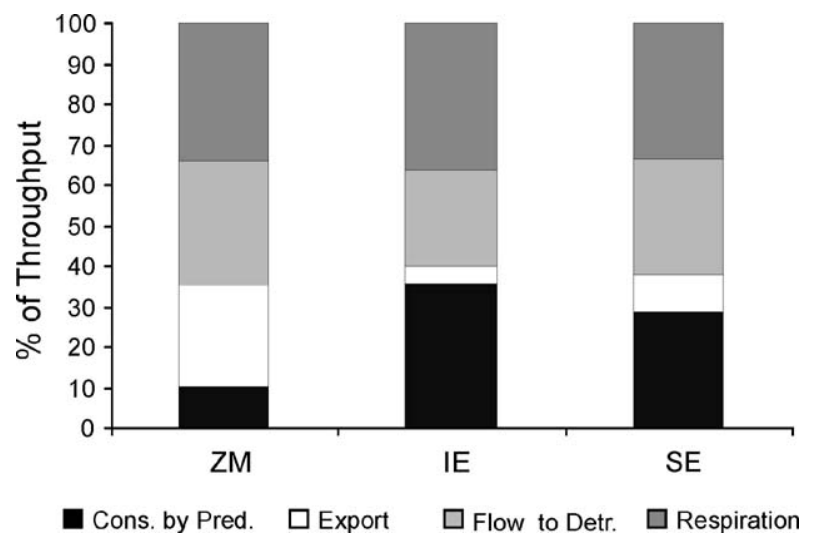

Fig. 2 - Partitioning of throughput among consumption by predators, exports, flow to detritus and respiration in the three estuarine areas. ZM, Zostera sp. meadows; IE, intermediate eutrophic area; SE, strongly eutrophic area. in the Mondego estuary has indicated that years of low precipitation have been associated with reductions in turnover rates and with increases in water column stability, salinity and light penetration (Martins et al., 2001). These changes in habitat conditions favoured the initiation of macroalgal blooms, which then served to depress the previously dominant macrophyte communities (Marques et al., 1997, 2003; Martins et al., 2001; Dolbeth et al., 2003; Cardoso et al., 2004). In the intermediate and strongly eutrophic areas, primary production is largely the result of such macroalgal blooms (Marques et al., 1997). As a consequence, production in these two systems appears as a strong pulse during the course of the blooms, but remains at very low levels for the rest of the year (Dolbeth et al., 2003). The short duration of the abundant primary production in these areas averages over the year to a significantly lower annual rate of net primary production. Odum (1969) had suggested that less-impacted systems (e.g. Zostera sp. beds) should exhibit higher rates of net system production-a fact that is consistent with the results of the current study. In fact, Patrício et al. (2004), by means of network analysis showed that when the whole-system properties of the three areas were compared, the measures associated with the area hypothesised as intermediate in terms of eutrophication symptoms did not present intermediate conditions at all. Rather, the intermediate eutrophic area exhibited the lowest ascendency, average mutual information, total system throughput and development capacity values and the highest figures for redundancy, cycling index, so to say it appears to be the most disturbed of the three areas. Moreover, it was suggested that the most likely explanation appears to be in the highly labile nature of the intermediate system. Indeed, observations using other ecological indicators (e.g. Shannon-Wiener, Margalef) have showed that the communities built around both edges of the eutrophication gradient (Zostera beds and Ulva sp. dominated areas) represent more stabilised communities. For more details regarding the eutrophication effects please see Patrício et al. (2004).

The system omnivory index (SOI) is the average group omnivory index weighted by the logarithm of the total food consumption. A group's omnivory index is calculated as the variance of the trophic levels of a consumer's preys (Christensen and Pauly, 1992). The SOI is a measure of how the feeding interactions are distributed between trophic levels (Vasconcellos et al., 1997). If a predator has only a prey on one trophic level its omnivory index will equal zero, while a large omnivory index indicates that the trophic positions of a predator's preys are variable. Heymans (2003), comparing different models of the Newfoundland community, observed that the reduction of a 50 compartments model to a 30 compartments model reduced the SOI in these systems. According to the author, this index is dependent on the number of compartments in the model: more compartments would have more connections and there would be less omnivory when compartments are combined and diets consolidated. However, in this study, the Zostera sp. meadows despite having $43 \mathrm{com}$ partments exhibited the lower value for this index. In fact, this community is the one with more groups, and still had the lowest SOI, which indicates that it is probably not an effect of different group size. 


\subsection{Transfer efficiency}

According to Lindeman (1942), ecosystem components can be grouped into discrete trophic levels, and transfer efficiencies estimated. Ecopath, using the trophic aggregation routine calculates the transfer efficiencies as the fraction of total flows at each trophic level (throughput) that are either exported or transferred to another trophic level through consumption. Since Lindeman (1942), it has often been assumed that trophic transfer efficiencies vary around $10 \%$, so that one-tenth of the energy that enters a trophic level is transferred to the next trophic level. Hence, transfer efficiencies are usually greater at the beginning of the food web compared with higher trophic levels, because of intrinsic characteristics of organisms at different levels in the food web (Christensen and Pauly, 1993). Nevertheless, the transfer efficiencies for the three studied areas (Table 3) suggest a pattern of low herbivore transfer efficiencies (most of the production does not originate from the Phytoplankton, but from the macroalgae and macrophytes whose embodied energy is available for consumers only after decaying into detritus), higher efficiencies on trophic level 3 and lower efficiencies at the higher levels. This fact has already been reported in the literature (e.g. Christensen and Pauly, 1993; Baird and Ulanowicz, 1989). Based on the system and the trophic level specific transfer efficiencies, Christensen and Pauly (1993) estimated the average transfer efficiency for different systems (as geometric mean, weighted after flow). The average efficiencies in the three areas in the south arm of the Mondego estuary (Table 3) are within the range of those described in the literature for temperate systems (3-7\%).

\subsection{Limitations and strengths of the approach}

The uncertainty over the input parameters for some of the groups at the lower trophic levels (e.g. Zooplankton, Phytoplankton) has already been discussed above. However, there were also several areas of uncertainty for groups at higher trophic levels (e.g. gulls, fishes, waders). Weakness in diet data has been noted in many compartments of the three models. The present models provided estimates of the contribution by various predators or groups of predators, but it must be clear that the diet information for all these predators is inadequate for obtaining accurate estimates of their consumption of minor preys. For example, the information on predation by many fish groups came largely from personal observations obtained at different sampling stations during a distinct time frame. These uncertainties are transmitted down the food web, since all productions and losses must be balanced for each group. A high consumption at the top of the food web requires high production at all lower levels. The model is particularly sensitive to some of the groups (e.g. H. diversicolor, C. crangon, C. maenas, Zooplankton, and Phytoplankton). The results described above indicate a system for which the available information contains significant uncertainty. As a consequence, there are several possible versions of the models.

Some other limitations of the model were observed, mainly associated with the steady-state assumption: high seasonal variations occurred, especially in the strongly eutrophic area following the macroalgae bloom event, and these produced major changes in the trophic structure and production. This is not reflected in the present models which report average conditions, but it could have been done by constructing seasonal models for each of the three situations. Moreover, uncertainty and time delays in processes associated with ecosystem dynamics were not considered, which will constrain their direct use for management purposes. Nevertheless, lack of historical data and difficulty in measuring some ecosystem components and processes will likely always plague efforts to understand trophic structure and interactions. This is not a problem with Ecopath, but rather with aquatic ecology in general (Ludwig et al., 1993).

Lastly, even with all the limitations that this approach seems to have, why are flux estimates vital to ecosystem science? Many hypotheses and concepts about ecosystem function and food web dynamics focus on the nature of flows of energy in these systems. For example, previous authors have proposed a number of ecosystem attributes, and hypothesised about their relationship to productivity, successional state, and the level of human disturbance in an ecosystem (Odum, 1969; Ulanowicz and Kay, 1991). Some of these attributes, such as gross production, community respiration quotients, energy cycling or feedback loops require estimates of fluxes between functional groups in their calculation. Patten (1995) showed that five indices used to describe ecosystems, Ascendency, Emergy, Eco-Exergy, Indirect Effects, and Maximum Power, are related through the structure of networks and flows of energy within the networks. Thus, most of the 'descriptive statistics' for ecosystems include transfers of energy between groups, and estimating fluxes is as fundamental to ecosystem and food web ecology as estimating demographic rates is to population ecology. In addition, to simply describe ecosystems or food webs, ecologists can also use this information to test hypotheses and draw conclusions regarding management decisions. Just as food webs were summarised and analysed

Table 3 - Trophic transfer efficiencies (\%) (proportion of energy transferred from one trophic level to the next) for each trophic group for the three estuarine networks

\begin{tabular}{|c|c|c|c|}
\hline \multirow[t]{2}{*}{ Trophic level } & \multicolumn{3}{|c|}{ Area } \\
\hline & Zostera sp. meadows & Intermediate eutrophic & Strongly eutrophic \\
\hline 2 & 6.6 & 8.9 & 3.7 \\
\hline 3 & 9.6 & 9.0 & 10.0 \\
\hline 4 & 4.2 & 5.4 & 5.8 \\
\hline 5 & 1.8 & 1.6 & 2.2 \\
\hline 6 & 1.1 & 1.5 & 0.8 \\
\hline 7 & 0.2 & 0.8 & 0.0 \\
\hline
\end{tabular}


for their structural characteristics (Pimm, 1982; Cohen et al., 1993), ecologists have now begun summarising the patterns of energy and nutrient flows between functional groups in food webs and ecosystems.

\section{Conclusions}

The Ecopath models presented here allowed summarising of our current knowledge of the biomass, consumption, production, food web and trophic flows in the three areas along the eutrophication gradient in the south arm of the Mondego estuary (Portugal).

These models also highlight data uncertainties allowing a gap analysis regarding our knowledge on the system (diet compositions, site-specific $\mathrm{P} / \mathrm{B}, \mathrm{Q} / \mathrm{B}$ ratios, ecological role of a number of abundant species, etc). Unfortunately, uncertainties concern all trophic levels and many constituent groups of the models, including some parameters regarding those groups that are regularly surveyed and assessed. Despite this, Ecopath with Ecosim provided a useful scheme for organising the communities' trophic structures.

As a final word, it is important to note that the process of constructing models such as these is essentially open-ended.
The data available for inputs are constantly being added to and revised. These models should be considered as a first step. Doubtless, the three models could be further enhanced, but these versions embody our closest approximation to the system, using the available data. Others are invited to critique the models structure, the input data, and the assumptions, so that the models can be improved in the future.

\section{Acknowledgements}

This research was carried out in the scope of the research project DYNAMOD (POCTI/MGS/37431/2001) and supported by FCT (Portuguese National Board of Scientific Research) through a grant SFRH/BD/820/2000, and by the IMAR - Institute of Marine Research/FLAD Grants program. Special thanks to Irene Martins, Isabel Jorge, Miguel A. Pardal, Ricardo Lopes and Ulisses Azeiteiro for making data available. Søren Nors Nielsen (Royal School of Pharmacy, Copenhagen) and J.J. Heymans (Fisheries Centre, Vancouver, BC) helped along the modelling phases.

\section{Appendix A. Models data sources}

\begin{tabular}{|c|c|c|}
\hline Compartments & Parameter & Source \\
\hline \multirow[t]{3}{*}{ Phytoplankton } & Biomass & Pardal (1998) \\
\hline & C:Chl a ratio & Anderson and Williams (1998) \\
\hline & $\mathrm{P} / \mathrm{B}$ & Wolff et al. (2000) \\
\hline Enteromorpha sp. & Biomass & Pardal (1998) \\
\hline Ulva sp. & $P / B$ & Aníbal (1998) \\
\hline \multirow[t]{2}{*}{ Gracilaria sp. } & Biomass & Pardal (1998) \\
\hline & $\mathrm{P} / \mathrm{B}$ & Duarte and Ferreira (1997) \\
\hline \multirow[t]{2}{*}{ Fucus } & Biomass & Pardal (1998) \\
\hline & $\mathrm{P} / \mathrm{B}$ & Niell et al. (1996) \\
\hline \multirow[t]{2}{*}{ Zostera noltii } & Biomass & Pardal (1998) \\
\hline & $P / B$ & $\begin{array}{l}\text { Sand-Jensen (1975) and Pérez-Lloréns and } \\
\text { Niell (1993) }\end{array}$ \\
\hline \multirow[t]{2}{*}{ Epiphytes } & Biomass & Pardal (1998) and Martins et al. (1999) \\
\hline & $\mathrm{P} / \mathrm{B}$ & Wolff et al. (2000) \\
\hline \multirow[t]{2}{*}{ Zooplankton } & Biomass and diet & Azeiteiro et al. (1999) \\
\hline & $\mathrm{P} / \mathrm{B}$ & Rosado-Salórzano and Próo (1998) \\
\hline \multirow[t]{4}{*}{ Hydrobia ulvae } & Biomass & Pardal (1998) \\
\hline & $\mathrm{P} / \mathrm{B}$ & Lillebø et al. (1999) and Sola (1996) \\
\hline & $P / Q$ & Hostens and Hamerlynck (1994) \\
\hline & Diet & $\begin{array}{l}\text { Hootsmans and Vermaat (1985), López- } \\
\text { Figueroa and Niell (1987), Morrisey (1988) } \\
\text { and Philippart (1995) }\end{array}$ \\
\hline \multirow[t]{4}{*}{ Gibulla umbilicalis } & Biomass & Pardal (1998) \\
\hline & $\mathrm{P} / \mathrm{B}$ & Baird and Milne (1981) \\
\hline & $P / Q$ & Hostens and Hamerlynck (1994) \\
\hline & Diet & Parker et al. (1993) and Watson (1985) \\
\hline \multirow{4}{*}{$\begin{array}{l}\text { Littorina sp. } \\
\text { L. littorea, L. saxatillis }\end{array}$} & Total biomass & Pardal (1998) \\
\hline & $P / B$ of the group & Baird and Milne (1981) \\
\hline & $P / Q$ of the group & Hostens and Hamerlynck (1994) \\
\hline & Diet & $\begin{array}{l}\text { Orth and Montfrans (1984), Konan et al. } \\
\text { (1992), Parker et al. (1993) and Watson (1985) }\end{array}$ \\
\hline
\end{tabular}


Appendix A (Continued)

\begin{tabular}{|c|c|c|}
\hline Compartments & Parameter & Source \\
\hline Melita palmate & Biomass & Pardal (1998) \\
\hline \multirow[t]{3}{*}{ Ampithoe valida } & $\mathrm{P} / \mathrm{B}$ & Pardal (1998) \\
\hline & $P / Q$ & Hostens and Hamerlynck (1994) \\
\hline & Diet & $\begin{array}{l}\text { Sprung (1994), Alonso et al. (1995) and Greze } \\
\text { (1968) }\end{array}$ \\
\hline \multirow[t]{3}{*}{ Echinogammarus marinus } & Biomass & Pardal (1998) \\
\hline & $\mathrm{P} / \mathrm{B}$ and diet & Marques and Nogueira (1991) \\
\hline & $P / Q$ & Hostens and Hamerlynck (1994) \\
\hline \multirow[t]{4}{*}{ Corophium multisetosum } & Biomass & Pardal (1998) \\
\hline & $\mathrm{P} / \mathrm{B}$ & Casabianca (1975) and Cunha et al. (2000) \\
\hline & $P / Q$ & Hostens and Hamerlynck (1994) \\
\hline & Diet & Cunha et al. (2000) and Smith et al. (1996) \\
\hline Scrobicularia plana & Biomass & Pardal (1998) \\
\hline Cerastoderma edule & $P / B$ & Sprung (1994) \\
\hline \multirow[t]{2}{*}{ Modiolus barbatus } & $P / Q$ & Hostens and Hamerlynck (1994) \\
\hline & Diet & $\begin{array}{l}\text { Hughes (1969), Loo (1992) and Prins and } \\
\text { Smaal (1989) }\end{array}$ \\
\hline \multirow[t]{3}{*}{ Cyathura carinata } & Biomass & Pardal (1998) \\
\hline & $\mathrm{P} / \mathrm{B}$ and diet & Ferreira et al. (2004) and Pardal (1998) \\
\hline & $P / Q$ & Hostens and Hamerlynck (1994) \\
\hline \multirow[t]{5}{*}{ Idotea chelipes } & Biomass & Pardal (1998) \\
\hline & $\mathrm{P} / \mathrm{B}$ & Sprung (1994) \\
\hline & $P / Q$ & Hostens and Hamerlynck (1994) \\
\hline & Diet & Nienhuis and Groenendijk (1986) and \\
\hline & & Schaffelke et al. (1995) \\
\hline \multirow[t]{3}{*}{ Sphaeroma hookeri } & Biomass & Pardal (1998) \\
\hline & $P / Q$ & Hostens and Hamerlynck (1994) \\
\hline & Diet & Pardal (1998) \\
\hline \multirow[t]{4}{*}{ Amage adspersa } & Biomass & Pardal (1998) \\
\hline & $\mathrm{P} / \mathrm{B}$ & Sprung (1994) \\
\hline & $P / Q$ & Hostens and Hamerlynck (1994) \\
\hline & Diet & Pardal (1998) and Sprung (1994) \\
\hline \multirow[t]{4}{*}{ Capitella capitata } & Biomass & Pardal (1998) \\
\hline & $\mathrm{P} / \mathrm{B}$ & Sprung (1994) \\
\hline & $P / Q$ & Hostens and Hamerlynck (1994) \\
\hline & Diet & $\begin{array}{l}\text { Tenore (1983) and Tenore and Chesney } \\
\text { (1985) }\end{array}$ \\
\hline \multirow[t]{3}{*}{ Heteromastus filiformis } & Biomass & Pardal (1998) \\
\hline & $P / B$ and diet & Sprung (1994) \\
\hline & $P / Q$ & Hostens and Hamerlynck (1994) \\
\hline \multirow[t]{4}{*}{ Hediste diversicolor } & Biomassa & Pardal (1998) \\
\hline & $\mathrm{P} / \mathrm{B}$ & Abrantes et al. (1999) and Sprung (1994) \\
\hline & $P / Q$ & Hostens and Hamerlynck (1994) \\
\hline & Diet & Nielsen et al. (1995) and Riisgård et al. (1996) \\
\hline \multirow[t]{4}{*}{ Diopatra neapolitana } & Biomass & Pardal (1998) \\
\hline & $\mathrm{P} / \mathrm{B}$ & Sprung (1994) \\
\hline & $P / Q$ & Hostens and Hamerlynck (1994) \\
\hline & Diet & Mangum et al. (1968) \\
\hline \multirow[t]{4}{*}{ Nephtys hombergii } & Biomass & Pardal (1998) \\
\hline & $\mathrm{P} / \mathrm{B}$ & Sprung (1994) \\
\hline & $P / Q$ & Hostens and Hamerlynck (1994) \\
\hline & Diet & Beukema (1987) and Oyenekan (1986) \\
\hline \multirow[t]{4}{*}{ Lumbrineris impatiens } & Biomass & Pardal (1998) \\
\hline & $P / B$ & Venier (1997) \\
\hline & $P / Q$ & Hostens and Hamerlynck (1994) \\
\hline & Diet & Petch (1986) and Valderhaug (1985) \\
\hline
\end{tabular}


Appendix A (Continued)

Compartments
Other macrofauna detritivores
Aonides oxycephala, Chaetozone setosa,
Lagis koreni, Polydora ligni, Pygospio elegans,
Streblospio shrubsolii, Haminea hydatis,
Diptera larvae

Other macrofauna predators

Nemertini, Glycera convoluta, M. picta, A. mucosa, P. laminosa

Oligochaeta
Tubificoides benedeni, Oligocheta sp.

Carcinus maenas

Crangon crangon

Microalgae and detritus feeders

Mugil cephalus, Chelon labrosus, Liza

aurata, Liza ramada, Alosa fallax, A. alosa

Zooplankton consumers

Sardina pilchardus, Syngnathidae,

Engraulis encrasicolus

Endofauna consumers

Solea vulgaris, Solea senegalensis,

Platichthys flesus

Macrofauna predators

Dicentrarchus labrax, Anguilla anguilla, Gobius niger, Ciliata mustela, Sparus aurata, Diplodus sargus, Diplodus vulgaris, Mullus surmuletus, Atherina boyeri, A. presbyter

Trigla lucerna

Pomatoschistus minutus

Parameter

Total biomass

$\mathrm{P} / \mathrm{B}$ of the group

$P / Q$ of the group

Diet

Total biomass

$\mathrm{P} / \mathrm{B}$ of the group

P/Q of the group

Diet

Total biomass

$P / B$ of the group

$P / Q$ of the group

Diet

Biomass

$P / B$

$P / Q$

Diet

Total biomass

$\mathrm{P} / \mathrm{B}, \mathrm{Q} / \mathrm{B}$ group

Stomach content

DW/WW, C/DW

Total biomass

$\mathrm{P} / \mathrm{B}, \mathrm{Q} / \mathrm{B}$ group

Stomach content

DW/WW, C/DW

Total biomass

$\mathrm{P} / \mathrm{B}, \mathrm{Q} / \mathrm{B}$ group

Stomach content

DW/WW, C/DW

Total biomass

$\mathrm{P} / \mathrm{B}, \mathrm{Q} / \mathrm{B}$ group

Stomach content

DW/WW, C/DW

Biomass

$\mathrm{P} / \mathrm{B}, \mathrm{Q} / \mathrm{B}$

Stomach content

DW/WW, C/DW

Biomass

$\mathrm{P} / \mathrm{B}, \mathrm{Q} / \mathrm{B}$
Pardal (1998)

Sprung (1994)

Source

Hostens and Hamerlynck (1994)

Dauer et al. (1981), Lambeck and Valentijn (1987) and Zajac (1986)

Pardal (1998)

Sprung (1994)

Hostens and Hamerlynck (1994)

Commito and Ambrose (1985), McDermott and Roe (1985), Ockelmann and Vahl (1970)

and Thiel and Reise (1993)

Pardal (1998)

Sprung (1994)

Hostens and Hamerlynck (1994)

Giere (1975)

Pardal (1998)

Sprung (1994)

Hostens and Hamerlynck (1994)

Ansell et al. (1999), Lee and Seed (1992) and

Pihl (1985)

Jorge (unpublished data)

http://www.fishbase.org

Correia et al. (1997), Oliveira and Soares (1996) and Jørgensen et al. (1991)

Jorge (unpublished data)

http://www.fishbase.org

Convay et al. (1994) and Jorge (unpublished data)

Jørgensen et al. (1991)

Jorge (unpublished data)

http://www.fishbase.org

Costa (1982), Gonçalves (1990) and Summers (1980)

Jørgensen et al. (1991)

Jorge (unpublished data)

http://www.fishbase.org

Correia et al. (1997), Costa (1982), Rebelo (1993) and Rosecchi (1987)

Jørgensen et al. (1991)

Jorge (unpublished data)

http://www.fishbase.org

Correia et al. (1997), Costa (1982) and Morte et al. (1997)

Jørgensen et al. (1991)

Jorge (unpublished data)

http://www.fishbase.org 
Appendix A (Continued)

\begin{tabular}{lll}
\hline Compartments & \multicolumn{1}{c}{ Parameter } & \multicolumn{1}{c}{ Source } \\
\hline & Stomach content & Costa (1982) and Jorge (unpublished data) \\
Larus ridibundus & Biomassa & Jørgensen et al. (1991) \\
Larus fuscus & P/B, Q/B & Lopes (unpublished data) \\
& Diet & http://www.cbl.umces.edu/ãtlss \\
& Av. weight/ind. & Moreira (1995) \\
Charadrius alexandrinus & DW/WW, C/DW & Cramp and Simmons (1983) \\
Charadrius hiaticula & Biomass & Jørgensen et al. (1991) \\
Pluvialis squatarola & P/B, Q/B & Lopes (unpublished data) \\
Calidris alpina & Diet & http://www.cbl.umces.edu/ãtlss \\
& Av. weight/ind. & Lopes et al. (1998) \\
Detritus & DW/WW, C/DW & Zwarts et al. (1990) \\
& Biomass (O.M in the sediment) & Jørgensen et al. (1991) \\
\end{tabular}

\section{REFERENCES}

Abrantes, A., Pinto, F., Moreira, M.H., 1999. Ecology of the polychaete Nereis diversicolor in the Canal de Mira (Ria de Aveiro, Portugal): population dynamics, production and oogenic cycle. Acta Oecologica 20, 267-283.

Allen, P.M., 1971. Relation between production and biomass. J. Fish. Res. Board Canada 28, 1573-1581.

Allen, P.M., 1988. Evolution: why the whole is greater than the sum of the parts. Ecodynamics: contributions to Theoretical Ecology, Part 1: evolution. In: Wolff, W., Soeder, C.J., Drepper, F.R. (Eds.), Proceedings of an International Workshop. Jülich, Germany, 19-20 October 1987. Springer-Verlag, Berlin, pp. 2-30.

Alonso, G., Tablado, A., Lopez-Gappa, J., Magaldi, N., 1995. Seasonal changes in an intertidal population of the amphipod Ampithoe valida Smith, 1873. Oebalia XXI, 77-91.

Anderson, T.R., Williams, P.J. le B., 1998. Modelling the seasonal cycle of dissolved organic carbon at station E1 in the English Channel. Estuarine Coastal Shelf Sci. 46, 93-109.

Aníbal, J.M., 1998. Impacte da macroepifauna sobre as macroalgas Ulvales (Chlorophyta) na ria Formosa. MSc Thesis, University of Coimbra, $73 \mathrm{p}$.

Ansell, A.D., Comely, C.A., Robb, L., 1999. Distribution, movements and diets of macrocrustaceans on a Scottish sandy beach with particular reference to predation on juvenile fishes. Mar. Ecol. Prog. Ser. 176, 115-130.

Arias-González, J.E., Nuñez-Lara, E., González-Salas, C., Galzin, R., 2004. Trophic models for investigation of fishing effect on coral reef ecosystems. Ecol. Modell. 172, 197-212.

Azeiteiro, U.M., Marques, J.C., Ré, P., 1999. Zooplankton annual cycle in the Mondego River estuary (Portugal). Arquivos do Museu Bocage III, 239-264.

Baird, D., Milne, H., 1981. Energy flow in the Ythan estuary, Aberdeenshire, Scotland. Estuarine, Coastal Shelf Sci. 13, 455-472.

Baird, D., Ulanowicz, R.E., 1989. The seasonal dynamics of the Chesapeake Bay ecosystem. Ecol. Monographs 59, 329-364.

Beukema, J.J., 1987. Influence of the predatory polychaete Nephtys hombergii on the abundance of other polychaetes. Mar. Ecol. Prog. Ser. 40, 95-101.

Brown, M.T., 2004. A picture is worth a thousand words: energy systems language and simulation. Ecol. Modell. 178, 83-100.

Bundy, A., Lilly, G.R., Shelton, P.A., 2000. A mass balance model of the Newfoundland-Labrador Shelf. Canadian Technical Report of Fisheries and Aquatic Sciences, 2310, xiv+ 157 p.
Cabral, J.A., Pardal, M.A., Lopes, R.J., Múrias, T., Marques, J.C., 1999. The impact of macroalgal blooms on the use of the intertidal area and feeding behaviour of waders (Charadrii) in the Mondego estuary (West Portugal). Acta Oecologica 20, 417-428.

Cardoso, P.G., Pardal, M.A., Lillebø, A.I., Ferreira, S.M., Raffaelli, D., Marques, J.C., 2004. Dynamic changes in seagrass assemblages under eutrophication and implications for recovery. J. Exp. Mar. Biol. Ecol. 302, 233-248.

Casabianca, M.L., 1975. Méthode de calcul de la production par estimation de la mortalité. Application à une population à structure complexe du crustacé Corophium insidiosum Crawford (Lagune de Biguglia, Corse), vol. 280. Comptes Rendus Hebdomadaires de Séances de L'Académie des Sciences, Paris, pp. 1139-1142.

Christensen, V, Walters, C.J., Pauly, D., 2004. Ecopath with Ecosim: a User's Guide. Fisheries Centre Research Reports, vol. 12. University of British Columbia, Vancouver, 154 p. (available online at http://www.ecopath.org and http://www.fisheries.ubc.ca).

Christensen, V., Pauly, D., 1992. A guide to the Ecopath II program (version 2.1.). ICLARM Software, 6-72.

Christensen, V., Pauly, D., 1993. Flow characteristics of aquatic ecosystems, Trophic Models of Aquatic Ecosystems. In: Christensen, V., Pauly, D. (Eds.), ICLARM Conference Proceedings, vol. 26. Manila, pp. 338-352.

Christensen, V., 1994. Energy-based ascendency. Ecol. Modell. 72, 129-144.

Cohen, J.E., Beaver, R.A., Cousins, S.H., DeAngelis, D.L., Goldwasser, L., Heong, K.L., Holt, R.D., et al., 1993. Improving food webs. Ecology 74, 252-258.

Commito, J.A., Ambrose, W.G., 1985. Multiple trophic levels in soft-bottom communities. Mar. Ecol. Prog. Ser. 26, 289293.

Convay, O.V., Coombs, S.H., Fernández de Puelles, M.L., Tranter, P.R., 1994. Feeding of larval sardine, Sardina pilchardus (Walbaum), of the north coast Spain. Boletín Instituto Español de Oceanografía 10, 165-175.

Correia, M.J., Costa, M.J., Gordo, L.S., 1997. Trophic groups of fish in the Óbidos lagoon (Portugal). Publicaciones Especiales del Instituto Español de Oceanografía 23, 153-160.

Costa, M.J., 1982. Contribution à l'étude de l'écologie des poissons de l'estuaire du Tage (Portugal). PhD Thesis. University of Paris VII, 256 pp.

Cramp, S., Simmons, K., 1983. The Birds of the Western Palearctic, vol. III, Waders to gulls. Oxford University Press, London. 
Cunha, M.R., Moreira, M.H., Sorbe, J.C., 2000. The amphipod Corophium multisetosum (Corophiidae) in Ria de Aveiro (NW Portugal). II. Abundance, biomass and production. Mar. Biol. 137, 651-660.

Dauer, D.M., Maybury, C.A., Ewing, R.M., 1981. Feeding behavior and general ecology of several spionid polychaetes from the Chesapeake Bay. J. Exp. Mar. Biol. Ecol. 54, 21-38.

Dolbeth, M., Pardal, M.A., Lillebø, A.I., Azeiteiro, U., Marques, J.C., 2003. Short- and long-term effects of eutrophication on the secondary production of an intertidal macrobenthic community. Mar. Biol. 143, 1229-1238.

Duarte, P., Ferreira, J.G., 1997. A model for the simulation of macroalgal population dynamics and productivity. Ecol. Modell. 98, 199-214.

Enriques, E., Duarte, C.M., Sand-Jensen, K., 1993. Patterns in decomposition rates among photosynthetic organisms: the importance of detritus C:N:P content. Oecologia 94, 457-471.

Ferreira, S.M., Pardal, M.A., Lillebø, A.I., Cardoso, P.G., Marques, J.C., 2004. Population dynamics of Cyathura carinata (Isopoda) in a eutrophic temperate estuary. Estuarine, Coastal Shelf Sci. 61, 669-677.

Flindt, M.R., Kamp-Nielsen, L., Marques, J.C., Pardal, M.A., Bocci, M., Bendoricchio, G., Nielsen, S.N., Jørgensen, S.E., 1997. Description and comparation of the three shallow estuaries: Mondego River (Portugal), Roskield Fjord (Denmark) and the lagoon of Venice (Italy). Ecol. Modell. 102, 17-31.

Giere, O., 1975. Population structure, food relations and ecological role of marine oligochaetes, with special reference to meiobenthic species. Mar. Biol. 31, 139-156.

Gonçalves, J.J., 1990. Fluxos de energia na cadeia trófica do estuário do Tejo: estudo da ecofase estuarina do elo Solea solea (Linnaeus, 1758) (Pisces, Soleidae). Final Report, Faculty of Sciences University, Lisbon.

Greze, I.I., 1968. Feeding habits and food requirements of some amphipods in the Black Sea. Mar. Biol. 1, 316-321.

Heymans, J.J., Baird, D., 2000. A carbon flow model and network analysis of the northern Benguela upwelling system, Namibia. Ecol. Modell. 126, 2-32.

Heymans, J.J., 2003. Ecosystem models of Newfoundland and Southeastern Labrador: additional information and analyses for 'Back to the Future'. Fisheries Centre Research Reports 11, $79 \mathrm{pp}$.

Hootsmans, M.J., Vermaat, J.E., 1985. The effect of periphyton-grazing by three epifaunal species on the growth of Zostera marina L. under experimental conditions. Aquatic Bot. 22, 83-88.

Hostens, K., Hamerlynck, O., 1994. The mobile epifauna of the soft bottoms in the subtidal Oosterscheld Estuary: structure, function and impact of the storm-surge barrier. Hydrobiologia 282/283, 479-496.

Hughes, R.N., 1969. A study of feeding in Scrobicularia plana. J. Mar. Biol. Assoc. U.K. 49, 805-823.

Jorge, I., Monteiro, C.C., Lasserre, G., 2002. Fish community of Mondego estuary: space-temporal organisation. In: Pardal, M.A., Marques, J.C., Graça, M.A. (Eds.), Aquatic Ecology of the Mondego River Basin. Global Importance of Local Experience. Imprensa da Universidade de Coimbra, pp. 199-217.

Jørgensen, S.E., 2002. Integration of Ecosystem Theories: A Pattern, 3rd ed. Kluwer Academic Publishers, The Netherlands, 420 pp.

Jørgensen, S.E., Nielsen, S.N., Jørgensen, L.A., 1991. Handbook of Ecological Parameters and Ecotoxicology. Elsevier Science Publishers, Amsterdam, The Netherlands, 1263 pp.

Konan, A., Cardinal, A., Lamontagne, I., 1992. Rythmes à court et à moyen termes associés au broutage de la microflore marine épilithique par Littorina saxatilis. Oceanologica Acta 15, 397-403.
Lambeck, R.H., Valentijn, P., 1987. Distribution, dynamics and productivity of a colonizing (Polydora quadrilobata) and an established (P. ligni) polydorid polychaete in Lake Grevelingen: an enclosed estuary in the SW Netherlands. Netherlands J. Sea Res. 21, 143-158.

Lee, S.Y., Seed, R., 1992. Ecological implications of cheliped size in crabs: some data from Carcinus maenas and Liocarcinus holsatus. Mar. Ecol. Prog. Ser. 84, 151-160.

Likens, G.E., 1985. An Ecosystem Approach to Aquatic Ecology: Mirror Lake and its Environment. Springer-Verlag, New York.

Lillebø, A.I., Pardal, M.A., Marques, J.C., 1999. Population structure, dynamics and production of Hydrobia ulvae (Pennant) (Mollusca: Prosobranchia) along an eutrophication gradient in the Mondego estuary (Portugal). Acta Oecologica 20, 289-304.

Lindeman, R.L., 1942. The trophic-dynamic aspects of ecology. Ecology 23, 399-418.

Loo, L.-O., 1992. Filtration, assimilation, respiration and growth of Mytilus edulis L. at low temperatures. Ophelia 35, 123131.

Lopes, R., Cabral, J.A., Múrias, T., Marques, J.C., 1998. Contribuição para o conhecimento da dieta do Pilrito-comum Calidris alpina e da Tarambola-cinzenta Pluvialis squatarola no estuário do Mondego. Airo 9, 27-32.

Lopes, R.J., Cabral, J.A, Pacheco, C., Múrias, T., Marques, J.C., 2002. Status and habitat use of waders in the Mondego estuary. In: Pardal, M.A., Marques, J.C., Graça, M.A. (Eds.), Aquatic Ecology of the Mondego River Basin. Global Importance of Local Experience. Imprensa da Universidade de Coimbra, pp. 219-230.

López-Figueroa, F., Niell, F.X., 1987. Feeding behaviour of Hydrobia ulvae (Pennant) in microcosm. J. Exp. Mar. Biol. Ecol. 114, 153-167.

Ludwig, D., Hilborn, R., Walters, C., 1993. Uncertainty, resource exploitation, and conservation: lessons from history. Science 260, 17-18.

Mangum, C.P., Santos, S.L., Rhodes, W.R., 1968. Distribution and feeding in the onuphid polychaete Diopatra cuprea (Bosc). Mar. Biol. 2, 33-40.

Marques, J.C., Nogueira, A., 1991. Life cycle, population dynamics, and production of Echinogammarus marinus (Leach) (Amphipoda) in the Mondego estuary (Portugal). Oceanologica Acta 11, 213-223.

Marques, J.C., Martins, I., Teles-Ferreira, C., Cruz, S., 1994. Population dynamics, life history, and production of Cyathura carinata (Krøyer) (Isopoda: Anthuridae) in the Mondego estuary (Portugal). J. Crustacean Biol. 14 (2), 258-272.

Marques, J.C., Pardal, M.A., Nielsen, S., Jørgensen, S.E., 1997. Analysis of the properties of Exergy and biodiversity along an estuarine gradient of eutrophication. Ecol. Modell. 102, 155-167.

Marques, J.C., Nielsen, S.N., Pardal, M.A., Jørgensen, S.E., 2003. Impact of eutrophication and river management within a framework of ecosystem theories. Ecol. Modell. 166, 147-168.

Martins, I., Oliveira, J.M., Flindt, M.R., Marques, J.C., 1999. The effect of salinity on the growth rate of the macroalgae Enteromorpha intestinalis (Chlorophyta) in the Mondego estuary (west Portugal). Acta Oecologica 20 (4), 259-265.

Martins, I., Pardal, M.A., Lillebø, A.I., Flindt, M.R., Marques, J.C., 2001. Hydrodynamics as a major factor controlling the occurrence of green macroalgal blooms in a eutrophic estuary. A case study on the influence of precipitation and river management. Estuarine, Coastal Shelf Sci. 52, 165-177.

McDermott, J.J., Roe, P., 1985. Food, feeding behaviour and feeding ecology of nemerteans. Am. Zool. 25, 113-125.

Moreira, F.M., 1995. A utilização das zonas entre-marés do estuário do Tejo por aves aquáticas e suas implicações para 
os fluxos de energia na teia trófica estuarina. PhD Thesis. Faculty of Science of the University of Lisbon.

Morrisey, D.J., 1988. Differences in effects of grazing by deposit-feeders Hydrobia ulvae (Pennant) (Gastropoda: Prosobanchia) and Corophium arenarium Crawford (Amphipoda) on sediment microalgal populations. I. Qualitative differences. J. Exp. Mar. Biol. Ecol. 118, 33-42.

Morte, M.S., Redon, M.J., Sanz-Brau, A., 1997. Trophic relationships between two gurnards Trigla lucerna and Aspitrigla obscura from the western Mediterranean. J. Mar. Biol. Assoc. U.K. 77, 527-537.

Neto, J.M., 2004. Nutrient enrichment in a temperate macro-tidal system. Scenario analysis and contribution to coastal management. PhD Thesis. University of Coimbra, 139 pp.

Niell, F.X., Fernández, C., Figueroa, F.L., Figueiras, F.G., Fuentes, J.M., Pérez-Llorens, J.L., Garcia-Sánchez, M.J., Hernández, I., Fernández, J.A., Espejo, M., Buela, J., Garcia-Jiménez, M.C., Clavero, V., Jiménez, C., 1996. Spanish Atlantic Coast. In: Shramm, W., Nienhuis, P.H. (Eds.), Marine Benthic Vegetation. Recent Changes and the Effects of Eutrophication. Springer Verlag, Berlin, pp. 7-43.

Nielsen, A.M., Eriksen, T.N., Iversen, J.J.L., Riisgård, H.U., 1995. Feeding, growth and respiration in the polychaetes Nereis diversicolor (facultative filter-feeder) and N. virens (omnivorous) - a comparative study. Mar. Ecol. Prog. Ser. 125, 149-158.

Nienhuis, P.H., Groenendijk, A.M., 1986. Consumption of eelgrass (Zostera marina) by birds and invertebrates: an annual budget. Mar. Ecol. Prog. Ser. 29, 29-35.

Ockelmann, K.W., Vahl, O., 1970. On the biology of the polychaete Glycera alba, especially its burrowing and feeding. Ophelia 8, 275-294.

Odum, E.P., 1969. The strategy of ecosystem development. Science 164, 262-270.

Oliveira, I.R., Soares, L.S.H., 1996. Alimentação da tainha Mugil platanus Gunther, 1980 (Pisces: Mugilidae), da região estuarino-lagunar de Cananéia, São Paulo, Brasil. Boletim do Instituto de Pescas 23 (único), pp. 95-104.

Orth, R.J., Montfrans, J.V., 1984. Epiphyte-seagrass relationships with an emphasis on the role of micrograzing: a review. Aquatic Bot. 18, 43-69.

Oyenekan, J.A., 1986. Population dynamics and secondary production in an estuarine population of Nephtys hombergii (Polychaeta: Nephtydae). Mar. Biol. 93, 217-223.

Patrício, J., Ulanowicz, R., Pardal, M.A., Marques, J.C., 2004. Ascendency as an ecological indicator: a case study of estuarine pulse eutrophication. Estuarine, Coastal Shelf Sci. 60, 23-35.

Pardal, M.A., 1998. Impacto da eutrofização nas comunidades macrobentónicas do braço Sul do estuário do Mondego (Portugal). PhD Thesis. University of Coimbra, 315 pp.

Pardal, M.A., Cardoso, P.G., Sousa, J.P., Marques, J.C., Raffaelli, D., 2004. Assessing environmental quality: a novel approach. Mar. Ecol. Prog. Ser. 267, 1-8.

Pardal, M.A., Marques, J.C., Metelo, I., Lillebø, A.I., Flindt, M.R., 2000. Impact of eutrophication on the life cycle, population dynamics and production of Ampithoe valida (Amphipoda) along an estuarine spatial gradient (Mondego estuary, Portugal). Mar. Ecol. Prog. Ser. 196, 207219.

Parker, T., Johnson, C., Chapman, A.R.O., 1993. Gammarid amphipods and littorinid snails have significant but different effects on algal succession in littoral fringe tidepools. Ophelia 38, 69-88.

Patten, B.C., 1995. Network integration of ecological extremal properties: Exergy, emergy, Ascendency, and indirect effects. Ecol. Modell. 79, 75-84.
Pérez-Lloréns, J.L., Niell, F.X., 1993. Seasonal dynamics of biomass and nutrient content in the intertidal seagrass Zostera noltii Hornem from Palmones River estuary, Spain. Aquatic Bot. 46, 49-66.

Petch, D.A., 1986. Selective deposit-feeding by Lumbrineris cf. latreilli (Polychaeta: Lumbrineridae), with a new method for assessing selectivity by deposit-feeding organisms. Mar. Biol. 93, 443-448.

Philippart, C.J., 1995. Effect of periphyton grazing by Hydrobia ulvae on the growth of Zostera noltii on a tidal flat in the Dutch Wadden Sea. Mar. Biol. 122, 431-437.

Pihl, L., 1985. Food selection and consumption of mobile epibenthic fauna in shallow marine areas. Mar. Ecol. Prog. Ser. 22, 169-179.

Pimm, S.L., 1982. Food Webs. Chapman and Hall, London, 219 pp.

Polovina, J.J., 1984. Model of a coral reef ecosystem I. The Ecopath model and its application to French Frigate Shoals. Coral Reefs 3, 1-11.

Prins, T.C., Smaal, A.C., 1989. Carbon and nitrogen budgets of the mussel Mytilus edulis L. and the cockle Cerastoderma edule (L.) in relation to food quality. Scientia Marina 53, 477-482.

Rebelo, J.E., 1993. A ictiofauna da Ria de Aveiro e o período lagunar do ciclo de vida do robalo, Dicentrarchus labrax Linnaeus, 1758. PhD Thesis. University of Aveiro, $180 \mathrm{pp}$.

Riisgård, H.U., Poulsen, L., Larsen, P.S., 1996. Phytoplankton reduction in near-bottom water caused by filter-feeding Nereis diversicolor-implications for worm growth and population grazing impact. Mar. Ecol. Prog. Ser. 141, 47-54.

Rosado-Salórzano, R., Próo, S.A., 1998. Preliminary trophic structure model for Tampamachoco lagoon, Veracruz, Mexico. Ecol. Modell. 109, 141-154.

Rosecchi, E., 1987. L'alimentation de Diplodus annularis, Diplodus sargus, Diplodus vulgaris et Sparus aurata (Pisces, Sparidae) dans le Golfe du Lion et les lagunes littorales. Revue des Travaux de l'Institut des Pêches Maritimes 49, 125-141.

Sand-Jensen, K., 1975. Biomass, net production and growth dynamics in an eelgrass (Zostera marina L.) population in Vellerup Vig, Denmark. Ophelia 14, 185-201.

Schaffelke, B., Evers, D., Walhorn, A., 1995. Selective grazing of the isopod Idotea baltica between Fucus evanescens and F. vesiculosus from Kiel Fjord (western Baltic). Mar. Biol. 124, 215-218.

Smith, D., Hughes, R.G., Cox, E.J., 1996. Predation of epipelic diatoms by the amphipod Corophium volutator and the polychaete Nereis diversicolor. Mar. Ecol. Prog. Ser. 145, 53-61.

Sola, J.C., 1996. Population dynamics, reproduction, growth, and secondary production of the mud-snail Hydrobia ulvae (Pennant). J. Exp. Mar. Biol. Ecol. 205, 49-62.

Sprung, M., 1994. Macrobenthic secondary production in the intertidal zone of the Ria Formosa-a lagoon in southern Portugal. Estuarine, Coastal Shelf Sci. 38, 539-558.

Strickland, J.D., Parsons, T.R., 1968. A practical hand-book of seawater analysis. Bull. Fish. Res. Board Can. 167, 1-311.

Summers, R.W., 1980. The diet and feeding behaviour of the flounder Platichthys flesus (L.) in the Ythan Estuary, Aberdeenshire, Scotland. Estuarine Coastal Mar. Sci. II, 217-232.

Tenore, K.R., Chesney, E.J., 1985. The effects of interaction of rate of food supply and population density on the bionergetics of the opportunistic polychaete, Capitella capitata (type 1). Limnol. Oceanogr. 30, 1188-1195.

Tenore, K.R., 1983. Organic nitrogen and caloric content of detritus. III. Effect on growth of a deposit-feeding polychaete, Capitella capitata. Estuarine Coastal Shelf Sci. 17, 733-742.

Thiel, M., Reise, K., 1993. Interaction of nemertines and their prey on tidal flats. Netherlands J. Sea Res. 31, 163-172. 
Ulanowicz, R.E., Kay, J.J., 1991. A package for the analysis of ecosystem flow networks. Environ. Software 6, 131143.

Valderhaug, V.A., 1985. Population structure and production of Lumbrineris fragilis (Polychaeta: Lumbrineridae) in the Oslofjord (Norway) with a note on metal content of jaws. Mar. Biol. 86, 203-211.

Vasconcellos, M., Mackinson, S., Sloman, K., Pauly, D., 1997. The stability of trophic mass-balance models of marine ecosystems: a comparative analysis. Ecol. Modell. 100, 125-134.

Venier, J.M., 1997. Seasonal ecosystem models of the Looe Key NMS, FL. MSc Thesis. University of British Columbia.
Watson, D.C., 1985. Dietary preferences on the common periwinkle, Littorina littorea (L). J. Exp. Mar. Biol. Ecol. 88, 193-211.

Wolff, M., Koch, V., Isaac, V., 2000. A trophic flow model of the Caeté mangrove estuary (North Brazil) with considerations for the sustainable use of its resources. Estuarine Coastal Shelf Sci. 50, 789-803.

Zajac, R.M., 1986. The effects of intra-specific density and food supply on growth and reproduction in an infaunal polychaete, Polydora ligni Webster. J. Mar. Res. 44, 339-359.

Zwarts, L., Ens, B.J., Kersten, M., Piersma, T., 1990. Moult, mass and flight range of waders ready to take off for long-distance migration. Ardea 78, 339-364. 